DOI: https://doi.org/10.34069/AI/2021.48.12.1

How to Cite:

Iziumova, I.V. (2021). The image of a Russian student and his attitude to the study of Non-Core disciplines. Amazonia Investiga, 10(48), 9-17. https://doi.org/10.34069/AI/2021.48.12.1

\title{
The image of a Russian student and his attitude to the study of Non-Core disciplines
}

\section{Образ Российского Студента и его Отношение к Изучению Непрофильных Дисциплин}

Received: November 3, 2021

Accepted: December 15, 2021
Written by:

Irina V. Iziumova ${ }^{1}$

https://www.elibrary.ru/author_profile.asp?id=1067965 https://orcid.org/0000-0001-7020-6811

\begin{abstract}
The main purpose of this article is to study the psychological attitude of representatives of the professional sphere to the consumer in the field of education and students to the study of noncore disciplines. To achieve the goal, methods of observation, polling, free associations, content analysis, mathematical and statistical methods were used. The image is characterized by subjects by different criteria, sometimes contradictory. The attitude of students of technical faculties to management disciplines contains cognitive, affective and behavioral components. It was revealed that at the intrapersonal level it is based on the assessment of the value of knowledge application in future professional activities. When teaching, students divide disciplines into core and non-core ones. At the interpersonal level, learning outcomes and forecast of their achievement are important. The desire for interpersonal similarity is manifested. At the intragroup level, behavior is explained by: effect of "group thinking", group defense mechanisms and identity and dynamics of collective experience in the learning process. At the intergroup level, the following prevails: assessment of the competencies of teachers, effectiveness of management of educational institution and exchange of views on the quality and value of training.
\end{abstract}

Keywords: image, attitude, competence, goal, values.

\begin{abstract}
Аннотация
Основной целью данной статьи является изучение психологического отношения представителей профессиональной сферы к потребителю в сфере образования и студентов к изучению непрофильных дисциплин. Для достижения цели использованы методы наблюдения, опроса, свободных ассоциаций, контент-анализ, математико-статистические методы. Образ характеризуется субъектами разными критериями, иногда противоречивыми. Отношение студентов технических факультетов к управленческим дисциплинам содержит когнитивные, аффективные и поведенческие компоненты. Выявлено, что на внутриличностном уровне оно основывается на оценке ценности применения знаний в будущей профессиональной деятельности. При обучении студенты делят дисциплины на профильные и непрофильные. На межличностном уровне важны результаты обучения и прогноз их достижения; проявляется стремление к межличностному сходству. На внутригрупповом уровне поведение объясняется: эффектом «группового мышления»; групповыми защитными механизмами, идентичностью и динамикой коллективного переживания в процессе обучения. На межгрупповом уровне превалирует: оценка компетенций преподавателей, эффективности управления учебным учреждением и обмен мнением о качестве, ценности обучения.
\end{abstract}

Ключевые слова: образ, отношение, компетенции, цель, ценности.

\footnotetext{
${ }^{1} \mathrm{PhD}$ in Psychological Sciences, Associate Professor, Moscow Aviation Institute (National Research University), Moscow, Russia.
} 


\section{Introduction}

The psychological attitude of a person is a phenomenon of the inner world, this emotionally colored experience associated with a subjective assessment of the object of the relationship, at different levels is accompanied by cognitive, conative and affective characteristics.

This article focuses on the effectiveness of teaching, which is associated with the sociopsychological characteristics of the teacher and the student, and is manifested by the attitude towards the world and society, others and towards oneself (value orientations, moral foundations and trust).

The image of a teacher and students is described from the perspective of society, state, employer, professional community and future consumers of educational services (student and parentcustomer)

Society points to the image of a teacher, who, first of all, has high professional competence in a particular field. The modern teacher is discussed in the media from the position of positivenegative events: \achievements of individual specialists, ethics of behavior, relationships with students, parents, limitations are discussed, and requirements for personal characteristics are highlighted. Scientific research of the psychological attitude of society to the teacher, parent-client and student is not enough.

Modern socio-economic requirements are based on specific characteristics of consumers. The peculiarity of training consists in the direct interaction of the bearer of knowledge and skills (for example, a teacher) and a host (for example, a student). The process is accompanied by the formation of an image on both sides of the relationship: before the start of interaction, in the very process of transferring educational information, its application, assessing the results obtained, in the short term and in long term. Thus, both sides are in a situation of limitations, conditions, variable factors and images may not coincide.

To achieve the set educational goal, the teacher, using pedagogical and methodological methods of teaching and upbringing, simultaneously performs a complex psychological procedure of acceptance, assessment, perception and "adjustment" to the student. When training specialists (educators, teachers and instructors), the main emphasis is on finding positive characteristics in a student and his motivation for approved behavior in various activities. These approaches fulfill the protective function of a psychological attitude to retain a specialist in a profession or a specialist's attitude to a profession, forming the desired image of a student.

Researchers draw our attention to the fact that the formation of a student's image by a teacher is carried out according to several criteria. The first criterion is the following: past and current achievements at the stages of studying the discipline, taking into account its specifics (academic performance, results of competitions, olympiads, quality of work performed, etc.). The second criterion includes the attitude towards the studied behavior (activity, interest, etc.). The third criterion includes an assessment of the potential for achievement, erudition, motives and learning values. An image can be formed on the basis of behavior, communication in different situations, appearance and manifestation of ethical maturity (personal and social). In the process of forming the image and assessing students in different disciplines, various social and psychophysiological personal characteristics are taken into account.

The attitude of society (government, employer, teacher and parent-customer) to education, training in different periods of time manifests itself in different ways. A student of the XXI century in Russia is perceived as an active social person. It also demonstrates individuality of behavior, acceptance and adjustment to the requirements of the external environment. Society without condemnation accepts the time restrictions of some groups of students for fullfledged education, due to inclusion in production activities due to a lack of material resources, desire for career growth, professional employment, realization of hobbies and interests not related to the direction of study, obligations taken to the family, team, production, etc.

The results of the study showed that the availability of information allows a modern person to independently search for the necessary information and apply it in everyday life, for selfeducation, self-training for educational, professional purposes and determine the significance. At the same time, the media note a lot of situations when the user could not understand the issues well enough and made mistakes that lead to serious consequences. In the educational sphere, a similar problem is noted: superficial study of various topics, problems, 


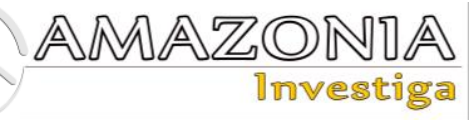

lack of analytical skills to establish cause and effect relationships, etc.

The attitude of 141 students to the acquisition of knowledge and management skills was studied using different types of questions before the start of the discipline. Differences in ideas about the importance of managerial competencies for production activities among students of different courses and areas of study were revealed. Some respondents express a positive opinion, some note that the managerial sphere of activity requires special training, and a small number noted the uselessness of these competencies for representatives of engineering and technical specialties. The relationship between the desired grade in the studied discipline, the cost to achieve it, and motives has been investigated.

Production problems, in which the student is not involved, attracts the least attention, the emotional sphere does not manifest itself brightly and is almost not accompanied by actions.

In general, the image and psychological attitude towards those who are engaged in the transfer and acquisition of knowledge, skills and abilities from representatives of society are associated with the perception of a person by a person, world, society, social role, status, professional activity and personal, everyday experience.

\section{Theoretical Basis}

The psychological attitude is revealed in the works of A.F. Lazursky (2019), V.N. Myasishchev (1995), B.F. Lomov (1981), K.K. Platonov (1972), E.V. Shorokhova, A. L. Zhuravlev (2001), P.N. Shikhirev (2003), I.R. Sushkov (2008), V.P. Poznyakov (2000), etc.

V.N. Myasishchev (1995) points to the multiplicity and interconnectedness of the psychological relationships of the individual, which explains their contradictoriness and complex nature. Personality attitudes are associated with socio-psychological phenomena and have several levels.

At the intrapersonal level, the attitude is based on morality, values, trust, social intelligence, identity and personality traits.

At the interpersonal level, the following are distinguished: interpersonal interaction and perceived interpersonal similarity.
At the intragroup level, the following are distinguished: effects of "group thinking", group defense mechanisms, group identity and dynamics of collective experiences in the learning process.

At the intergroup level, the following are distinguished: trust in members of identical or different group.

Attitude towards the state and social institutions, national characteristics and culture is a societal factor.

According to E. B. Shestopal (2016), D. S. Kuznetsova (2016) and B. G. Ananyev (2020) student performance has an impact on the assessment process.

A.A. Bodalev (1982) and V.N. Mezinov (2007) draw attention to the fact that the behavior of students, appearance and quality of work performed distort the real characteristics.

S.V. Kondratyeva (1980) supplements the list with characteristics related to the characteristics of the subject being studied. For example, a teacher in exact disciplines in the image of a student includes logical thinking, and in creative, engineering, management he includes figurative, associative thinking.

N.M. Bozhko and V.N. Mezinov notes that the teacher identifies and uses the personality traits of the student (Bozhko et al., 2002; Mezinov, 2007).

The pedagogical experience as a factor influencing the objectivity of the formed image is indicated by A.A. Rean and V. N. Mezinov (Mezinov, 2007; Bordovskaya \& Rean, 2009).

V.N. Koziev (1987), A.A. Bodalev (1982), D.S. Kuznetsova (2016) and V.N. Mezinov (2007) warn about the "oversimplified student image" that the teacher is developing. He recommends creating own professional model, norm and standard of conduct.

I.V. Romashova (2013) indicates images of a student who enjoys learning: he knows how to learn. In her opinion, the indicators should be unified and agreed upon. The value lies in cognitive activity, which manifests itself in interaction, communication, community or disagreement and oppositional views. The outcome is recognized as personal and collective development (Kuznetsova, 2016; Shestopal, 2016). 
The author believes that the ideal student, before entering the university, understands and realizes his place in life, in the profession and profession in his life. His behavior and character reflect the level of personal and social maturity. During professional development, a young person shows his attitude towards society, people of different status and age. The ideal student is "already brought up" or "he is successfully educating himself". He creates his own world, his ideal image, studies efficiently and professionally, learns the basics of his future profession in order to become a highly qualified specialist in the future. The ideal student is socially active in the study group, educational institution and community. He is a highly organized adult with a mature consciousness, who understands his place in the human world and strives for the highquality realization of his potential.

V. N. Mezinov (2007) and E.B. Shestopal (2016) emphasize that in the public consciousness, students belong to a special group of activities and have specific images and attitudes.

The student differs in style of behavior, manner of communication and appearance. During training, the student's personal qualities are developed or acquired in three ways:

1. it refers to the culture of speech, in which there is no obscene language; when communicating and in everyday interaction, politeness is always present;

2. intellectual development and erudition, breadth, specificity of knowledge and skills, ingenuity, ingenuity and installation to acquire knowledge;

3. good breeding, intelligence and general cultural level.

In the public mind, a student who has such qualities as politeness and good breeding, the modesty acquires independently. Such qualities as intelligence, education and level of culture are formed at the university. Students are distinguished by purposefulness, responsibility and discipline (Shestopal, 2016).

The idleness and frivolity of students is accepted or condemned by the society. Material wellbeing is more often attributed to the student's parents, rather than seen as an achievement of the individual. Students' motivation to learn has changed: from knowledge to prestige.

D.S. Kuznetsova (2016) asserts that the success of students reflects the experience they have acquired and this is the result of pedagogical activity. The winner of the competitions is a versatile personality. He communicates with friends, carries out social activities, but the main thing is education, inclusion in science, i.e. he is aimed at the future, profession and career.

Among the many psychophysiological qualities, there is the focus on: business, social, communicative sphere, manifestation of volitional characteristics, professional competence, moral and ethical principles and values.

\section{Methodology}

Attitude is associated with socio-psychological characteristics, which reflect the attitude towards the world and society, towards oneself and others, i.e. at different levels of psychological attitudes there will be different assessments, emotions and behavior of students towards the study of disciplines.

It seems important to determine the student's goal for studying non-core disciplines, following the basic postulates of A.N. Leontiev (1977), that first there must be a goal, and then a motive for achieving it.

When training specialists, educational standards are used, teachers are guided by them and develop training programs for students. At the same time, the goals of the state, educational institution, its individual divisions, teachers and students can be multidirectional.

The peculiarity of the interaction between the teacher and the student lies in the limited and in some cases inability to apply economic, administrative methods of management. Sociopsychological methods of managing the educational process of students and study groups remain relevant and effective. The teacher constantly monitors the activity and inclusiveness, he evaluates the assimilation of knowledge and acquisition of skills and analyzes the reasons for success and failure.

Personal and organizational characteristics give reason to choose methods of observation, polling, method of free associations and content analysis as a research tool, and for processing the results, mathematical and statistical methods using SPSS 22.0.

Observation will provide information about the attitude of students to learning in general and about the study of non-core disciplines. The number of visits, behavior outside the classroom 


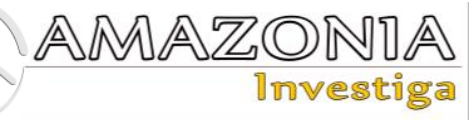

and in the classroom are recorded, when the regulators are "on" or not.

Questioning and conversation helps to reveal the reasons for avoiding assignments, skipping classes and other behavioral manifestations, i.e. motives. The motive to study the discipline can be expressed in the fear of punishment or the desire for development, discipline, taking for granted, inevitable, understanding of the applied application of the knowledge and skills acquired.

The method of free associations is used to identify unconscious knowledge gained from one's own experience or from other people, reactions, experiences and other states. It helps to determine the true, real attitude to the object and situation. The specificity of the method lies in the limited time of the answer to the question posed. This eliminates the deliberation for socially desirable answers, "embellishing" themselves and distorting the attitude to the subject of discussion.

Content analysis is addressed in order to identify the characteristics, properties of the studied subject, as well as attitudes towards it. Texts are investigated: scientific, artistic, personal letters, reports, explanatory notes and oral speech. In the process of work, the most common descriptions are first selected and then the data is sequentially grouped.

Open-ended questions are formulated for students of technical faculties studying the disciplines: "Management", "Personnel management", "Management decisions", "Consulting and audit" about the need for them to acquire managerial competencies, a short substantiation of their opinion.

The mastering of any course ends with the assessment of the results of mastering the course by the teacher. Management activity contains decision-making skills, analysis of one's own decisions and an assessment of the factors that influenced the achieved result. Thus, self-esteem is an important personal characteristic of the leader; therefore, the question of the desired grade at the end of the semester for the course being studied is included.

The amount of resources (personal time, finances, etc.) that students are willing to spend on studying the discipline or to achieve the desired grade depends on the interest in the subject.
The pedagogical task is to form the skills of designing one's own activities, assessing the complexity of completing tasks. We motivated the student to predict the result, taking into account the goal set by him with the help of the question: "What efforts are you willing to make to obtain the desired grade".

The topic of management, production problems from various sources, participation in events and discussions allows identifying interest in the study of non-core disciplines.

The first research question is aimed at studying students' ideas about the importance of managerial competencies for production activities.

We assumed that the high importance of knowledge and skills is interconnected with the assessment and costs for their formation: this is a reflection of the student's motivation, on the one hand. On the other hand, the student learns to predict future results and assess their own capabilities. For this, a question was asked about the desired grade in the studied discipline. An additional question is the following: "What efforts are you willing to put into obtaining the desired score" will help to confirm or disprove our hypothesis.

The results of the study, perhaps, will make it possible to adjust the content of the curriculum for students of different directions, specialties of training. The answers will help the teacher to form the content of the assignments, the volume for certain groups of students. The question is the following: "Do you pay attention to managerial, production problems discussed in society, family, among friends or presented in works of art and media?" If yes, have you thought about the reasons for their occurrence? If yes, who are you discussing them with? If you do not discuss, what sources do you refer to, where do you find the answer to your question or solutions to the problem. If not, why not? The answers allow studying the depth of students' interest in management problems, as well as clarifying with the help of what approaches and techniques this form of motivation was satisfied.

Description and Justification for the Selection of the Group for the Study

Students are involved directly or indirectly in the socio-economic processes of society: some of them assess the organization of the educational process and some of them combine learning with 
work, so, both subgroups have an idea of the role of management.

The study involved 84 full-time students at the technical faculties of Moscow Aviation Institute (National Research University), they have bachelor qualifications, and they are studying the discipline "Management". 45\% of them study in the second year, 50\% are third year students and $5 \%$ are fourth year students. They are 20-22 years old. $32 \%$ of the surveyed students work.

The study involved students (57 people), enrolled in full-time and part-time education, qualifications bachelor (3-4 years) and master (1 year). At the time of the survey, they study the discipline "Personnel management" (22 people), "Management decisions" (18 people) and "Consulting and audit" (17 people). All respondents work.

The total number of people who took part in the study was 141 . According to statistics, there is an uneven distribution by age, gender, work experience and positions held in the organization. We did not set the task of identifying features for these categories; therefore we do not provide data.

\section{Results}

Most of the students of the first group (76.19\%) have not studied the subject "Management" before, $15.48 \%$ have some idea of the subject and $5.95 \%$ have studied earlier without going deeply into the subject.

$58.9 \%$ of the respondents believe that they need the "Management" course for general development or self-development. 55\% of these are second year students, $30 \%$ are third year students and $15 \%$ are fourth year students.

They study the subject because it is included in the curriculum: out of the total number of students surveyed $16.67 \%$ are of the second year, $50 \%$ are of the third year and $33.33 \%$ are of the fourth year).

They do not know or do not fully understand for what purpose they need knowledge and skills in professional activity or society $(23.8 \%$ of students), $4.5 \%$ believe that it is not necessary to study and $4.66 \%$ did not answer the question.

To the question: "What skills will you acquire by studying this course?" the following results were obtained.
To learn: to work in a team: $22.62 \%(47.37 \%$ second year, $42.11 \%$ - third year, $10.53 \%$ - fourth year), to manage the team: $32.14 \%(33.33 \%$ second year, $51.85 \%$ - third year, $14.81 \%$ - fourth year), to manage time $13.1 \%(9.09 \%$ - fourth year, $18.18 \%$ - third year, $72.73 \%$ - second year).

A small proportion of students $(8.33 \%)$ assume that knowledge of this subject will help to increase the level of performance of the enterprise in which they will work $(14.29 \%$ fourth year, $42.86 \%$ - third year, $42.86 \%$ - second year).

The skills acquired in "Management" will help $1.19 \%$ of third year students to write their course or final work of higher quality.

Interest in studying the course "Management" among students of different courses differs and is distributed in this way. Among second year students, $35.9 \%$ have an interest in the subject, while $53.85 \%$ have none at all, and $10.26 \%$ of respondents believe that their interest depends on the teacher.

Distribution of results among third year students is the following: interested $-20.59 \%$, indifferent - $58.82 \%$, not knowing how to relate to the subject $-17.65 \%$.

Fourth year students (27.6\%) are interested in studying the discipline, almost half of the total number in this group (45.5\%) are not interested.

Most of the second year respondents $(77.38 \%)$ are ready to make an effort to get a positive high assessment in this subject. $11.9 \%$ of these will use their potential and resources to the maximum while studying the discipline, $9.5 \%$ will use the minimum, and the rest will inertly perform tasks, act at random, hoping for a successful situation, etc.

Third year students will be highly active in $2.6 \%$ of cases to get a high mark. $63.7 \%$ will attend lectures and practical classes and strive to prove themselves and not to waste time on completing assignments outside the classroom.

The results among fourth year students were distributed as follows: ready to complete assignments, but not to the detriment of other subjects $-79.76 \%$, make a minimum of effort $10.71 \%$, will complete work in excess of the curriculum $-8.33 \%$, the rest did not answer.

The ratio between the desired grade (DG), the number of people who attended classes (NAC) 


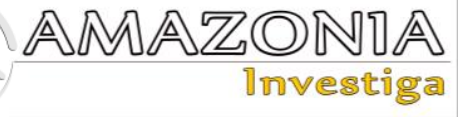

(lectures, practical exercises, laboratory work) and those who completed the full scope of tasks (CFST) is the following: DG at the level of "good" and "excellent" was expressed by 40 to $80 \%$ of respondents in all groups. NAC in the second year is up to $80 \%$, in the third year it is up to $60 \%$ and in the fourth it is up to $75 \%$. CFST: in the second year it is up to $70 \%$, in the third year it is up to $50 \%$ and in the fourth year it is up to $60 \%$.

\section{Discussion}

V.N. Koziev (1987) notes: a teacher should not form a simple image of a student. We fully share this position. We should create the own concept of attitudes for the implementation of professional tasks. This is especially important for teachers with little work experience in an educational institution, but with life experience (for recent students). Of course, we need clear ideas about our own values and priorities. Values are support, constant internal censorship, guide and assistant for all occasions.

Behavior indicates the level of personal and social maturity of an individual. I.V. Romashova (2013) describing the "ideal student" anticipates: the teacher does not need to make efforts or spend his resources on re-education. In professional practice, students have different levels of self-awareness and upbringing, social activity in the group, in the life of the university and beyond, i.e. attitude to learning. The educational process is accompanied by mutual enrichment of knowledge, skills and emotions and for the high-quality realization of one's potential.

Teachers learn the personal characteristics of students through personal communication, which is limited and does not allow a comprehensive individual approach to its solution: choice of method, form of training, personal assignment, etc. Knowledge about the level of motivation for cognition, power, self-realization, the level of reactive and personal anxiety, desire for safety and other characteristics of a student is the path to partnership.

V.S. Kuznetsova (2016) notes the value for the "student-winner" of the learning process and future profession, social and scientific activities. The students who do not participate in contests, olympiads and other competitive events have motives that are not related to recognition, respect and power. Achieving the desired grade in a non-core discipline is not accompanied by significant costs, since the object and subject in the direction of study is important for students of technical faculties

In the image of the winning student, the author includes professional norms, ethical principles and values, which, in the author's opinion, will contribute to his competitiveness as a future professional.

The "ideal" student knows how to learn and enjoys learning. He shows cognitive activity, knows how to interact, communicate, shares views or defends his own one or collective point of view, can act as an oppositionist, i.e. develops harmoniously. An "ideal" student understands and knows his mission, profession, is included in social life, as he is prepared for it or is at the stage of formation. The author has not described the image of the "imperfect" student. Characteristics of behavior, its cognitive abilities and emotional assessments can be either opposite to those listed above or positive ones.

The image of a student in the public consciousness is accompanied by negative characteristics of the student body in terms of financial support: "students do not study very seriously, because they hope that money will decide everything", etc. Higher well-being is attributed to the parents of the student, and the facts are not taken into account. Modern students study and work or only study. At the same time, those who are only engaged in educational activities, would very much like to work in order to be financially independent or gain work experience, think about their future career: each one has its own goal, motives, opportunities and limitations.

Students' motivation for learning has changed: from knowledge to prestige and status. Competencies allow finding a job in an attractive position. Objectively, this presupposes material reward, attitude of others to the position held, further professional and personal growth.

The results of the study indicate that there are more people who want to get high marks than those who will make an effort to achieve. That is, the student shows a rational attitude to the study of non-core disciplines and acts as a consumer. It determines the value of new knowledge and skills, possible benefits (scholarships, promotion, etc.) and necessary resources to obtain them according to their own criteria: finances, personal time, psychophysiological efforts or consequences in case of failure to complete tasks (Karpova et al., 2020). 
The attitude towards the study of management disciplines is associated with social, psychological and professional factors. During a certain period, Russian society developed an ambivalent attitude towards management. First, management is not recognized as a science, second, education in this area is easier to get than in other areas, third, title of the position (manager, head, etc.) sounds attractive, prestigious, but in terms of content it has a different attitude. Perhaps this influenced the idea of the future generation and its environment when choosing a profession (Morselli \& Passini, 2015).

The attitude to the study of non-core disciplines among students of technical faculties is due to the following factors: they do not plan to engage in managerial activities, for this it is necessary to additionally study and acquire special training; humanities are secondary disciplines, their study does not require much effort, they are not accurate and are not significant for high-tech industries. At the same time, managers of different management levels indicate that modern business not only presupposes, it dictates the following: all professional and personal characteristics are necessary for a manager's competencies (Stammel et al., 2015).

The motivation to study management disciplines is explained by socio-psychological characteristics. Second year students overcame the period of adaptation to study at a university and a new team, with pleasure and readiness to accept new knowledge. They are interested in everything. Some of them have not decided on their profession and specialty, they do not have knowledge about the competencies for the chosen and desired position, the attitude towards the chosen profession has changed (Kitova \& Uzdenov, 2009).

By the fourth year, the student realizes the ultimate goal of studying at the university, for everyone it is different: self-development, to graduate from a university, to take a position or to apply skills in practical activities.

The identified motives of students to study management disciplines and their ideas about the applied application of the acquired knowledge and skills provide teachers with additional information for the implementation of work programs, the choice of the form and method of teaching, correction of individual and group tasks.

\section{Conclusion}

An image is an idea of an object (real and/or desired one). A person uses it for comfort, to save effort, to gain an additional resource or to save him. An image is something that a person accepts, cannot accept or does not want to accept it as it is in reality; therefore it describes it from the perspective of its own ideas and attitudes. An image is not a statically perceived object, its characteristics by subjects at different times in different psychoemotional and psychophysiological states are perceived based on different criteria and their characteristics. In the public mind, the image is described by desirable, sometimes contradictory characteristics.

Conceptual theory of relationships about the multiplicity and complexity of them with the world, oneself and other people refers to social and psychological phenomena. Social responsibility, personal and psychophysiological characteristics of a person (intellectual, motivational, volitional) affect the attitude towards the subject/object and distinguish levels: intrapersonal, interpersonal, intragroup, intergroup and societal.

Management disciplines are assessed by the majority of students of technical faculties with a share of criticism and pragmatism, which is explained by pronounced cognitive abilities: logical and structural thinking. The attitude of students to the study of non-core disciplines is manifested in emotional description, moral and ethical assessment and behavior. They respect the chosen future profession, noting the complexity of studying the exact sciences and the ease of the humanities. At the intrapersonal level, the attitude towards the study of non-core disciplines is based on an assessment of the values of the future (status, career, remuneration). At the interpersonal level it is based on the learning outcomes and forecast of their achievement and the perceived interpersonal similarity. At the intragroup level, the factors of influence include the effects of "group thinking", group defense mechanisms, group identity and dynamics of collective experiences in the learning process. At the intergroup level it is based on the assessment of teachers and exchange of views on the quality, value of learning and management knowledge, students of the group and leadership of the educational institution.

Second year students begin to master non-core and special disciplines. In the process of 


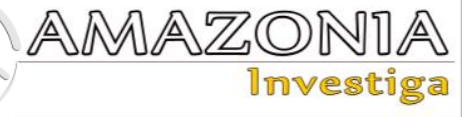

mastering, they divide them into complex and easy ones; whether or not they are related to professional activities. They have a positive attitude towards completing tasks and show interest in additional loads. Third year students will not spend much effort to get the grade they want. Assess the benefits of the liberal arts to them is at a low level. For fourth year students gaining experience as disciplined executives, the managerial issues of the organization are not important, but they are willing to take on assignments.

Interest in management is shown by students involved in professional and social activities, regardless of the course in which they are trained.

Thus, the most favorable time for the introduction of management disciplines into the curriculum is the first and the second year. First, we need to instill self-management skills, and in the next courses, to study more in-depth "Management".

It is possible to change the attitude towards the study of non-core disciplines by introducing additional classes and electives that students attend, and the program and topics can be developed taking into account their interests.

\section{Bibliographic references}

Ananyev, B. G. (2020). From the defense experience of Soviet psychology. Human capital, 4, 11-14. Retrieved at https://www.elibrary.ru/item.asp?id=42835162

Bodalev, A. A. (1982). Perception and understanding of a person by a person. Moscow: University.

Bordovskaya, N. V., \& Rean, A. A. (2009). Pedagogy. St. Petersburg: Peter. Retrieved at https://www.elibrary.ru/item.asp?id=22948644

Bozhko, N. M., Kanatov, A. I., Sokolovskaya, E. A., \& Shadrina, T. V. (2002). Adult education: goals and values. St. Petersburg: Institute of Pedagogical Education and Adult Education of the Russian Authors' Society. (In Russian)

Karpova, E. B., Isurina, G. L., \& Zhuravlev, A. L. (2020). The psychological concept of VN Myasishchev's relations: fundamentals and content. Psychological Journal, 41(2), 5-14. (In Russian)

Kitova, D. A., \& Uzdenov, T. M. (2009). Students' ideas about the goals and means of achieving economic well-being. Humanization of Education, 3, 129-133. Retrieved at https://cyberleninka.ru/article/n/predstavleniyastudentov-o-tselyah-i-sredstvah-dostizheniyaekonomicheskogo-blagopoluchiya
Kondratyeva, S. V. (1980). The teacher's understanding of the student's personality. Psychology Issues, 5, 143-148.

Koziev, V. N. (1987). Formation of professional qualities of the teacher's personality. Leningrad: Knowledge. (In Russian)

Kuznetsova, D. S. (2016). The image of the winning student: the view of the experts. Young Scientist, 15(1), 2-7. (In Russian)

Lazursky, A. F. (2019). General and experimental psychology. Moscow: URAIT. (In Russian)

Leontiev, A. N. (1977). Activity. Consciousness. Personality. Moscow: Politizdat. (In Russian)

Lomov, B. F. (1981). On the problem of activity in psychology. Psychological Journal, 2(5), 3-22. (In Russian)

Mezinov, V. N. (2007). Orientation of teacher education towards the preparation of a competitive teacher. Higher education in Russia, 4, 79-83. Retrieved at https://www.elibrary.ru/item.asp?id=9488657

Morselli, D., \& Passini, S. (2015). Measuring prosocial attitudes for future generations: The social generativity scale. Journal of Adult Development, 22(3), 173-182.

Myasishchev, V. N. (1995). Relationship Psychology. Voronezh: MODEK. (In Russian)

Platonov, K. K. (1972). On the system of psychology. Moscow: Thought. (In Russian)

Poznyakov, V. P. (2000). Psychological relations of subjects of economic activity. Moscow: Institute of Psychology of the Russian Academy of Sciences.

Romashova, I. P. (2013). The model of institutional discourse from the standpoint of the sociodynamic approach. Omsk University Bulletin, 1(67), 94-100. (In Russian)

Shestopal, E.B. (2016). Images of the future in the minds of Russian society as a factor of political development. Moscow University Bulletin. Series 12. Political Sciences, 2, 7-20. (In Russian)

Shikhirev, P. N. (2003). The nature of social capital: a socio-psychological approach. Social sciences and modernity, 2, 17-32.

Shorokhova, E. V., \& Zhuravlev, A. L. (2001). Psychology of joint life of small groups and organizations. Moscow: Institute of Psychology of the Russian Academy of Sciences. Retrieved at

https://www.elibrary.ru/item.asp?id=21002116

Stammel, N., Bockers, E., Neuner, F., Chhim, S., Taing, S., \& Knaevelsrud, C. (2015). The readiness to reconcile inventory. European Journal of Psychological Assessment, 33(6), 436-444.

Sushkov, I. R. (2008). Psychological relations of a person in the social system. Moscow: Institute of Psychology of the Russian Academy of Sciences. (In Russian) 